\title{
New perspectives on the evolution of the genus Typhlatya (Crustacea, Decapoda): first record of a cavernicolous atyid in the Iberian Peninsula, Typhlatya miravetensis $\mathrm{n}$. sp.
}

\author{
Sebastián Sanz ${ }^{1} \&$ Dirk Platvoet ${ }^{2}$ \\ ${ }^{1}$ Unitat d'Ecologia, Facultat de Ciències Biològiques, Universitat de València, E-46100 Burjassot, \\ València, Spain; ${ }^{2}$ Institute for Systematics and Population Biology (Zoological Museum, Amsterdam), \\ University of Amsterdam, P.O. Box 94766, 1090 GT Amsterdam, The Netherlands
}

Keywords: Typhlatya, Decapoda, Spain, subterranean waters, systematics, zoogeography, vicariance, evolution, key to genus

\begin{abstract}
On several occasions, shrimps belonging to a new species of the genus Typhlatya were collected in a cave in the province of Castellon, Spain. This is the first record of the genus in the Iberian Peninsula. The species is described and the validity, distribution, and zoogeography of the genus, as well as the status of the genus Spelaeocaris, are discussed. Former models for the evolution of the genus Typhlatya and its genus group are reviewed, as well as the system of inner classification of the Atyidae and its biogeographical meaning. For the age and evolution of the genus we developed a new model based on vicariance principles that involves further evolution of each species after the disruption of the ancestral range. This allows new estimations for the age of the genus. Accordingly, we suppose that other proposals, such as recent dispersal through the sea, should be disregarded for this genus. The evolutionary development of this species is discussed in the context of the geological history of the area and the world distribution of the genus, the genus group, and the family.
\end{abstract}

\section{Resumen}

En diversas ocasiones se capturaron camarones pertenecientes a una nueva especie del género Typhlatya en una cueva de la provincia de Castellón (España). Esta constituye la primera cita del género en la Península Ibérica. La especie es descrita y se discute sobre la validez, la distribución y la zoogeografía del género, así como sobre el estatus del género Spelaeocaris. Se revisan anteriores modelos sobre la evolución del género y la serie, así como el sistema de clasificación interna de los atiídos y su significado biogeográfico. Respecto a la edad y evolución del género, desarrollamos un nuevo modelo basado en principios de vicariancia que considera la evolución posterior de cada especie después de la disrupción del rango ancestral. Esto permite aportar nuevas estimaciones respecto a la edad del género. De acuerdo con este modelo, otras propuestas, como dispersión reciente por el mar, deberían desestimarse para este género. Se comenta el desarrollo evolutivo de esta especie en base a la historia geológica de la zona y la distribución mundial del género, del grupo de géneros, y la familia.

\section{Introduction}

In 1993 and 1994, shrimps were caught on several occasions in a cave near Cabanes, in the province of Castellón, eastern Spain. The specimens belong to the genus Typhlatya Creaser, 1936, a genus with members known from the Galápagos Islands, Ascension Island, Bermuda, and the Caribbean area (Mexico, Cuba, Dominican Republic, Mona Island, Barbuda, Puerto Rico, Caicos Islands, Bonaire, and Curaçao) (cf. Holthuis, 1986; Banarescu, 1990; Stock, 1993). Up to the present, members of the genus have not been recorded in Eurasia.

Several works have dealt with the origin and biogeography of the genus group, the genus, or some of its species (Monod \& Cals, 1970; Croizat et al., 1974; Monod, 1975; Rosen, 1976; Iliffe et al., 1983; Banarescu, 1990; Stock, 1993).

In spite of the coherent vicariance models suggested by several authors cited above, a general agreement on the evolutionary history of the genus is far from being reached. In other works, a recent dispersal through the sea has been considered (Chace \& Hobbs, 1969; Peck, 1974; Hart et al., 1985; Stock, 1986). The occurrence of a member of the genus in the Iberian Peninsula made us reconsider the different theories and formulate our ideas about the evolution of both this new species and the whole genus. 


\section{Systematic part}

Typhlatya miravetensis $\mathrm{n}$. sp.

(Figs. 1-4)

Material examined. - Male holotype, $20.7 \mathrm{~mm}$, female allotype, $18.5 \mathrm{~mm}$, and two female paratypes, 11.9 and $13.3 \mathrm{~mm}$ (coll. no. ZMA De. 201475, a, b, c). Cave "Ullal de la Rambla de Miravet" between the towns of Cabanes and Orpesa, province of Castellón, eastern Spain (UTM coordinates: 30T YK 504447), 30 June 1993. Conductivity $615.2 \mu$ mhos; chloride $25 \mathrm{mg} / \mathrm{l}$, pH 7.01; water temp. $24^{\circ} \mathrm{C}$. Accompanying fauna: Typhlocirolana sp. (Isopoda: Flabellifera).

Other material: same locality, 10 specimens, March 1994.

Description of holotype. - Habitus illustrated (Fig. 1a). Length $20.7 \mathrm{~mm}$. Rostrum short, not reaching beyond eyestalks, almost absent. Eyes without pigment. First peduncular segment of antennule as long as second and third combined, flagella subequal in length, between half and two-thirds of body length (Figs. 1a, b), outer flagellum with proximal fourteen segments swollen. Stylocerite slender, not reaching beyond first peduncular segment. Antennal scaphocerite (Fig. 1e) reaching well beyond peduncle; distal tooth on straight outer margin at $80 \%$ of total length. Inner flagellum $35 \%$ longer than body. Outer flagellum one-segmented and extremely reduced.

Mandibles with row of hairs between molar and incisor (Figs. 1c, d). Palp absent. Small projection present at base of upper lobe of first maxilla (Fig. 1f), inner margin with row of setules near base of strong teeth. Inner edge of lower lobe with long setae of varying length. Palp one-segmented with three small setae near apex. Membranous structure at mid-length on palp of second maxilla (Fig. 2b), near connection between scaphognathite and palp. First maxilliped (Fig. 2a) with long flagellar lobe, distal lobe of exopodite reduced. Epipodite small but distinct, thumb-shaped. Second maxilliped as illustrated (Fig. 2c). Flagellum of exopodite of third maxilliped (Fig. 3a) with podobranch and small epipodite. Segmentation between basis and ischium indistinct.

Exopodites of pereiopods decreasing in relative length from anterior to posterior (Figs. 3b-e, 4a). Ischium and merus separate in all pereionods, ischium always shorter than merus. Exopodite of fifth pereiopod reaching beyond ischium (Fig. 4a). Epipodites present on pereiopods 1 to 4. Dactylus of fifth pereiopod distinctly longer than that of pereiopods 3 and 4. Pereiopod 5 longest.

First pleopod (Fig. 4b) with short inner ramus; no appendix interna present. Second pleopod (Fig. $4 \mathrm{e})$ with appendix interna and short appendix masculina with nine setules implanted near apex. Pleopods 3 (Fig. 4c) to 5 with subequal rami and appendix interna.

Uropods (Fig. 4d) long and slender. Diaeresis with short spine on posterodistal corner and three setules. Telson (Fig. 2d) with one pair of lateral spines and 13 spines on posterior margin, intermixed with two small setae. Two longitudinal rows of setules on dorsal surface.

Female: Except for the second pleopod, where the females lack the appendix masculina, no sexual dimorphism was found.

Remarks. - This species fits well within the definition of the genus (see Creaser 1936; Monod \& Cals, 1970; Hobbs et al., 1977): absence of spines on carapace, rostrum never overreaching antennular peduncle and lacking spines, first through fifth pereiopods with exopodites, first to fourth pereiopods with epipodites.

The species diagnosis is based on a combination of characters that makes it different from all other species of the genus (see below): very short rostrum, absence of eye pigment, ischium and merus of pereiopods not fused, exopodite of fifth pereiopod well developed. A key to the species of Typhlatya is given in the Appendix.

Derivatio nominis. - The specific name, miravetensis, refers to the mediaeval name of "Tinença de Miravet", where the cave is located.

Ischium-merus fusion. - In some species of Typhlatya, fusion of the ischium and merus in the pereiopods occurs (Table I). In many groups, such as amphipods, a character like this is considered to be of generic value. This could imply that the genus Typhlatya might be divided into as many as six sub- 


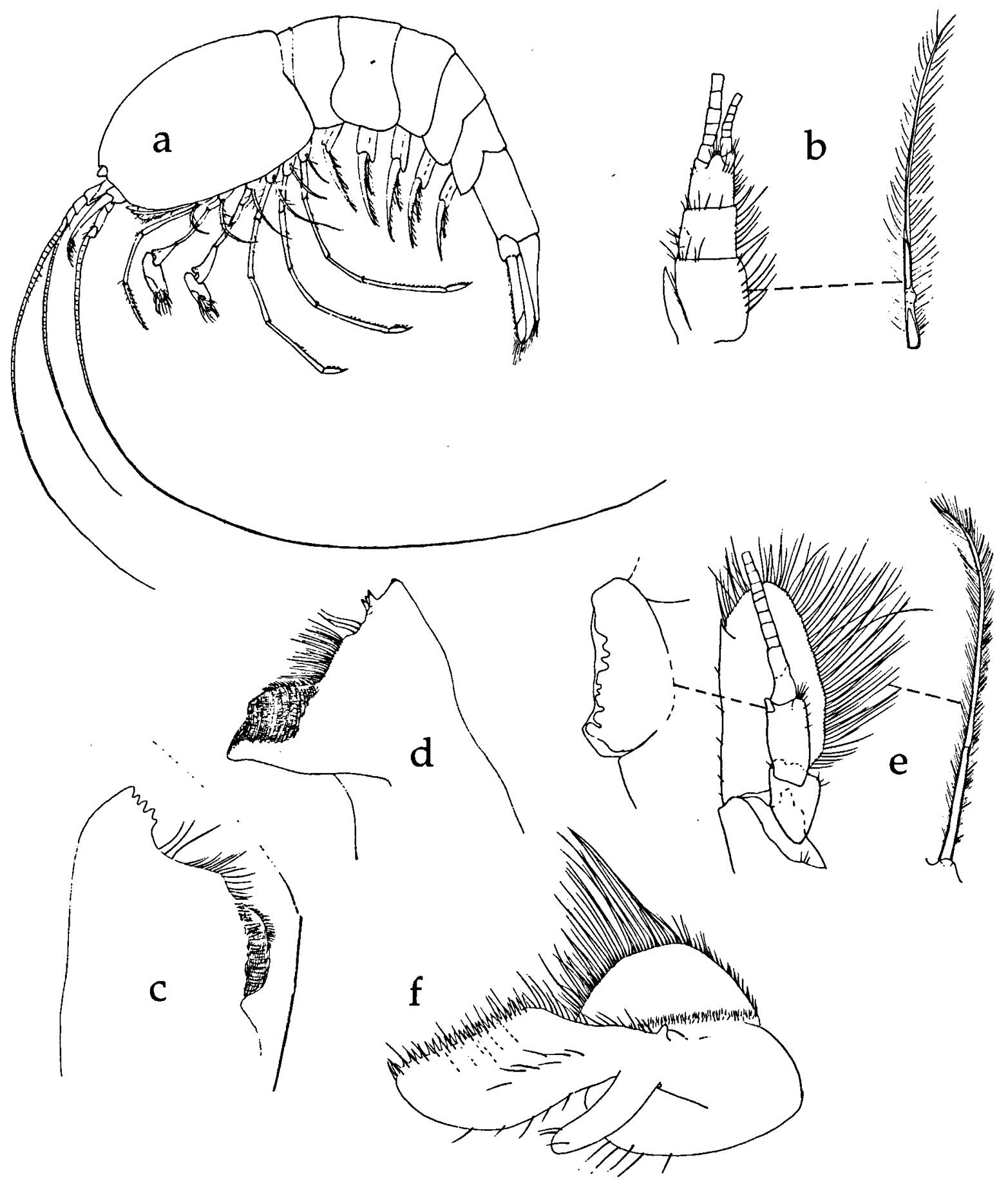

Fig. 1. Typhlatya miravetensis $\mathrm{n}$. sp.: a, habitus; b, first antenna with enlarged seta from segment 1 (scales III and V); c, left mandible (I); d, right mandible (I); e, second antenna with enlarged seta from antennal scale and detail of distal part of peduncle (III); f, first maxilla (IV). 

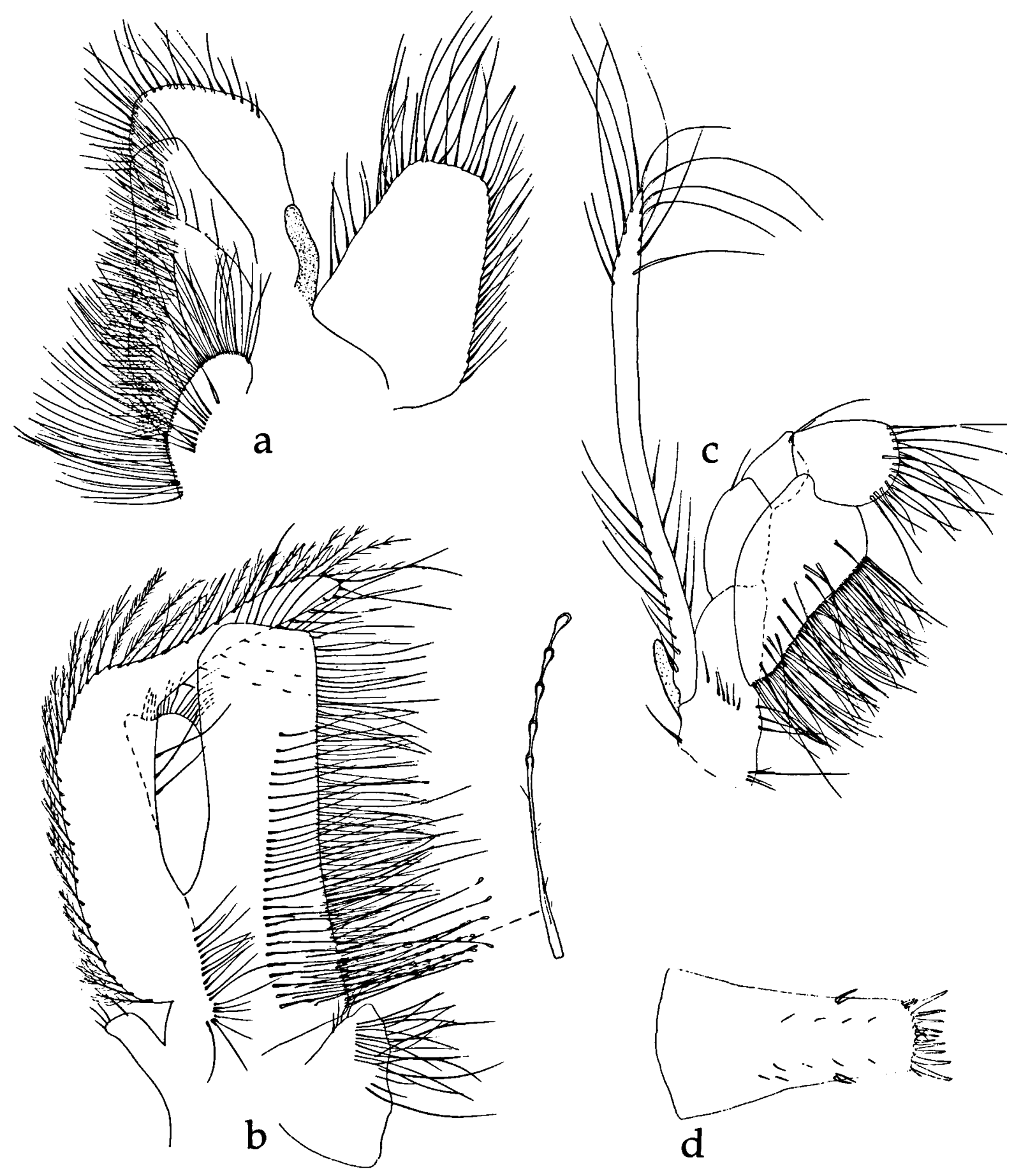

Fig. 2. Typhlatya miravetensis n. sp.: a, first maxilliped (scale IV); b, second maxilla (IV); c, second maxilliped (IV); d, telson (II). 

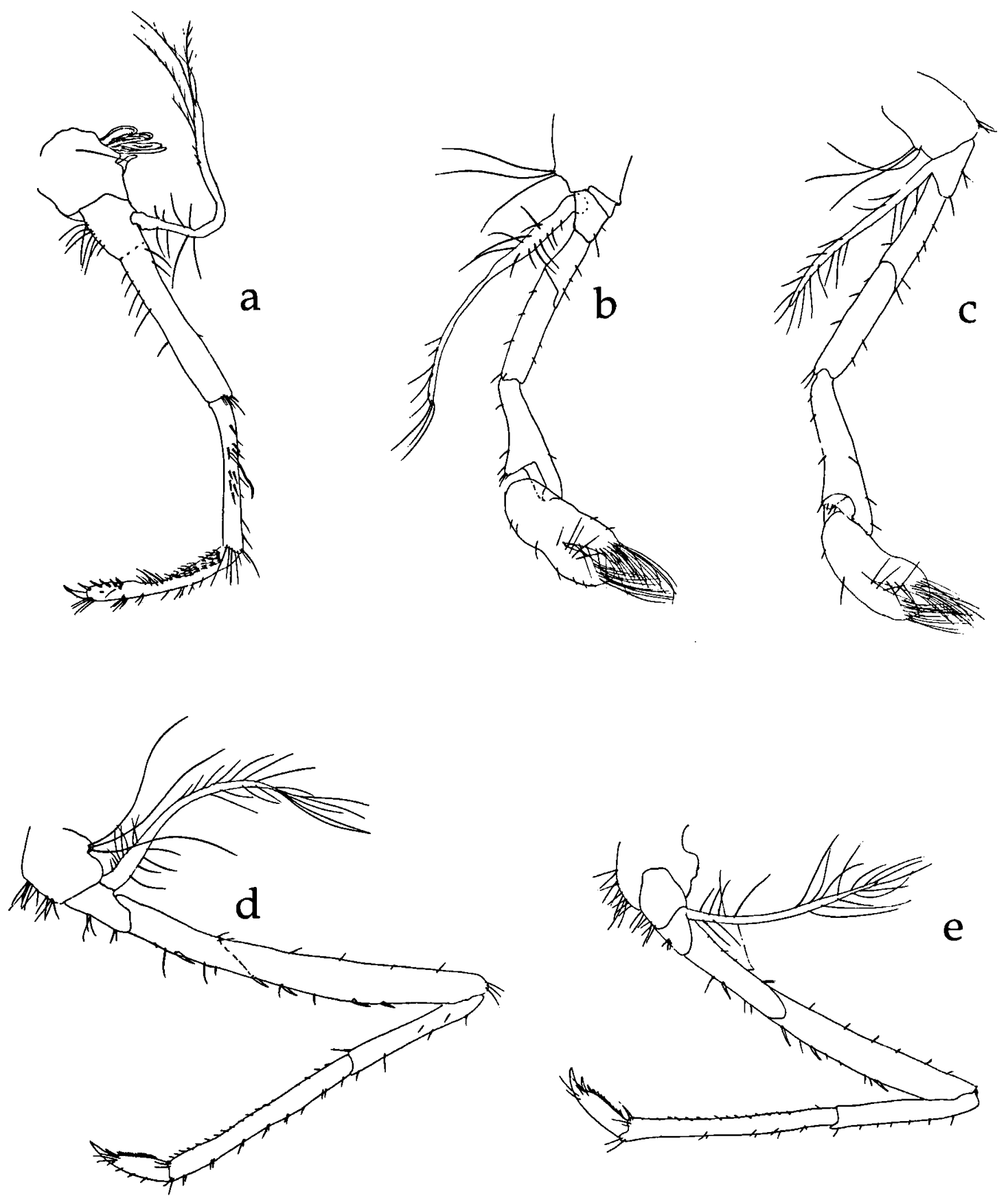

Fig. 3. Typhlatya miravetensis n. sp.: a, third maxilliped (scale II); b, first pereiopod (II); c, second pereiopod (II); d, third pereiopod (II); e, fourth pereiopod (II).

groups. However, since other characters (rostrum, eye pigmentation, exopodite $\mathrm{P} 5$ reduction) do not support such a division we consider the genus Typhlatya, for the time being, as a workable taxon.
Typhlatya pretneri (Matjašic, 1956) new rank

The genus Spelaeocaris (S. pretneri Matjašic, 1956), which is found in Hercegovina (former 

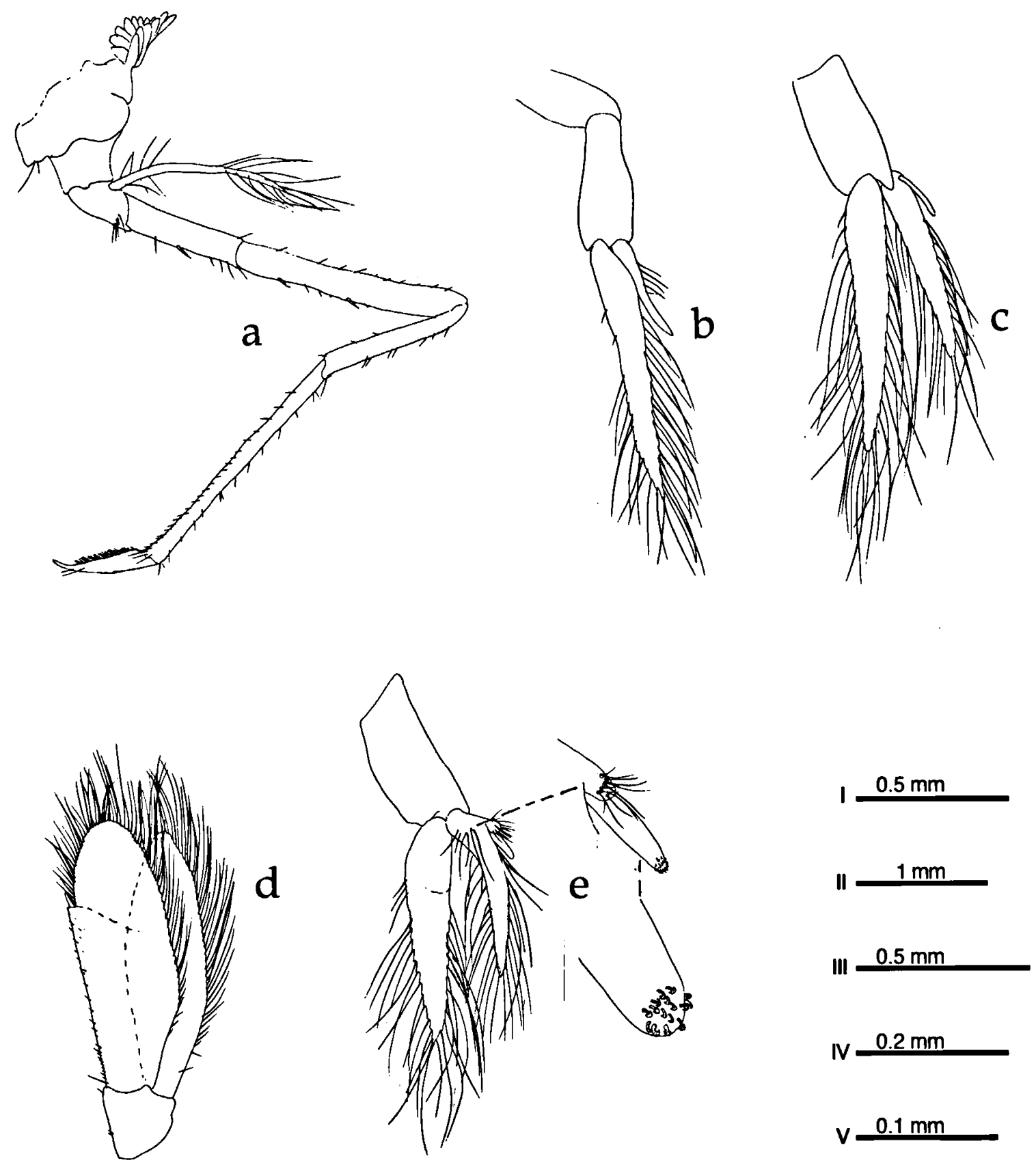

Fig. 4. Typhlatya miravetensis n. sp.: a, fifth pereiopod (scale II); b, first pleopod (II); c, third pleopod (II); d, uropod (II); e, second pleopod with details (II, IV, V).

Yugoslavia), is distinguished from Typhlatya by the reduction of the exopodites of the pereiopods (Monod \& Cals, 1970). Nevertheless, in their review of the "série Typhlatyienne", these authors did not point out that in Typhlatya monae Chace, 1954 and
$T$. pearsei Creaser, 1936, the exopodites of the pereiopods are also gradually reduced from P1 to P5. Another character used by Monod \& Cals for retaining the genus Spelaeocaris is the number of distal spines on the telson. Since their study, two more 
Table I. Fusion of ischium and merus of pereiopods and other characters in the genus Typhlatya (exop. = exopodite). Keys: (a) $2=$ not fused, 1 = fused; (b) - = eyes unpigmented, $+=$ eyes pigmented; (c) 1 = long, $s=$ short; (d) exopodite P5, $1=$ long, $s=$ short; (e) presence $(+)$ of distal setae on exopodites of pereiopods.

\begin{tabular}{|c|c|c|c|c|c|c|c|}
\hline \multirow[t]{2}{*}{ species } & \multicolumn{3}{|c|}{ fusion of ischium and merus } & \multirow[t]{2}{*}{ eye } & \multirow[t]{2}{*}{ rostrum } & \multirow[t]{2}{*}{ exop. P5 } & \multirow[t]{2}{*}{ setae exop. } \\
\hline & $\mathbf{P 1}, 2$ & P3, 4 & P5 & & & & \\
\hline campecheae & 2 & 2 & 2 & - & $\mathbf{s}$ & 1 & + \\
\hline garciai & 2 & 2 & 2 & + & $\mathbf{s}$ & 1 & - \\
\hline miravetensis & 2 & 2 & 2 & - & $\mathbf{s}$ & 1 & + \\
\hline monae & 2 & 2 & 2 & - & $\mathbf{s}$ & $\mathbf{s}$ & + \\
\hline pearsei & 2 & 2 & 1 & - & 1 & s & + \\
\hline mitchelli & 2 & 1 & 2 & - & 1 & s & + \\
\hline galapagensis & 2 & 1 & 1 & - & $\mathbf{s}$ & 1 & - \\
\hline consobrina & 1 & 2 & 2 & + & 1 & 1 & + \\
\hline rogersi & 1 & 2 & 2 & + & 1 & 1 & + \\
\hline iliffei & 1 & 1 & 1 & + & 1 & 1 & + \\
\hline pretneri & 1 & 1 & 1 & - & 1 & $\mathbf{s}$ & - \\
\hline Key: & (a) & (a) & (a) & (b) & (c) & (d) & (e) \\
\hline
\end{tabular}

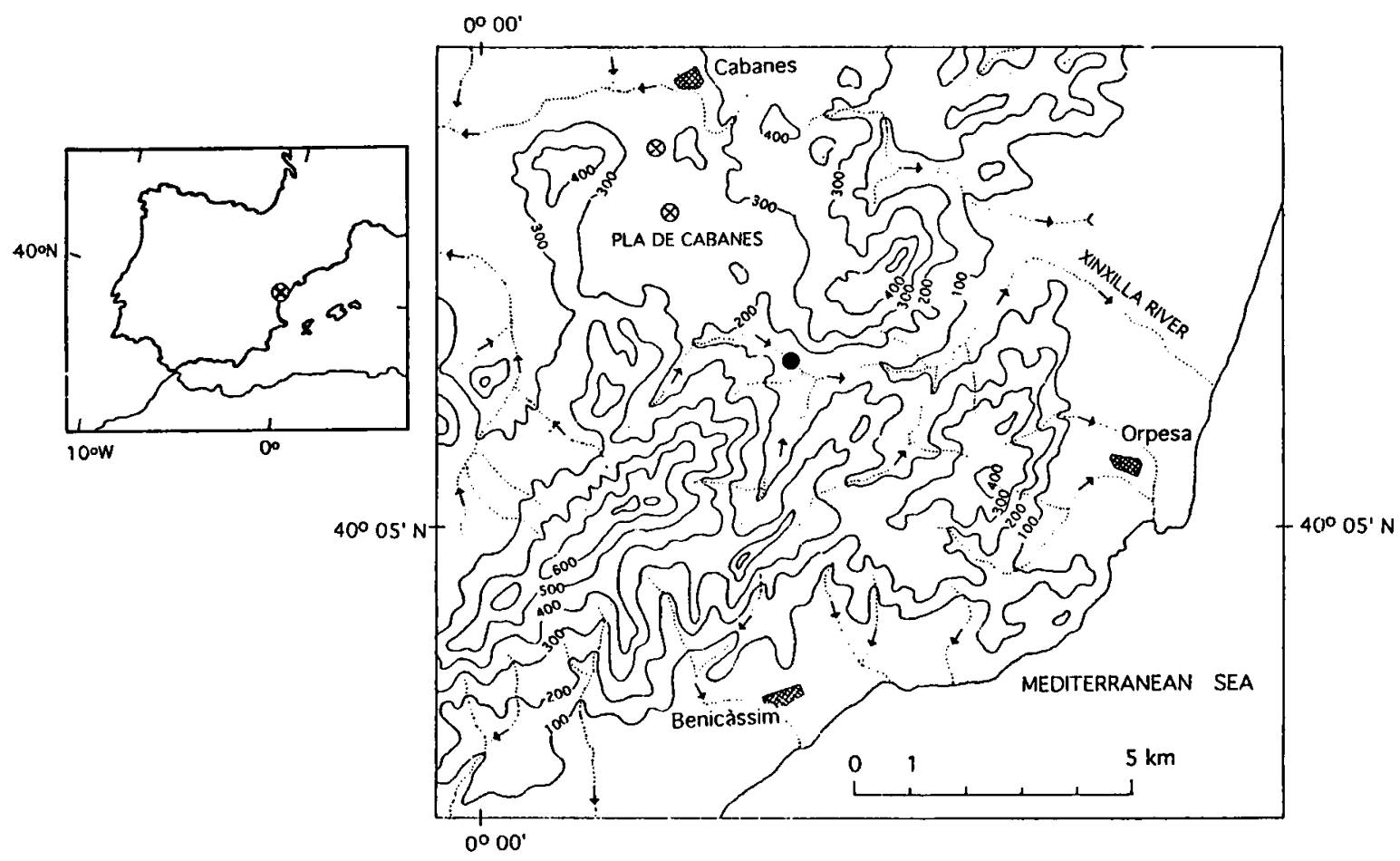

Fig. 5. Map of the area in which the cave is located. The solid dot represents the mouth of the cave. The crossed dots indicate two karstic holes that possibly represent the water inlets of the system involved. The surface hydrological network of the area is represented by dotted lines. This network is solely formed by temporary rivers. The arrows indicate the direction of the water flow.

species have been assigned to the genus Typhlatya: T. iliffei Hart \& Manning, 1981 and T. miravetensis. These two bear ten or more distal spines on the telson; so, these Typhlatya species show some overlap with the genus Spelaeocaris.

With this in mind the status of the genus Spelaeocaris becomes uncertain. Convergent reductions of exopodites frequently occurred in decapods. After 


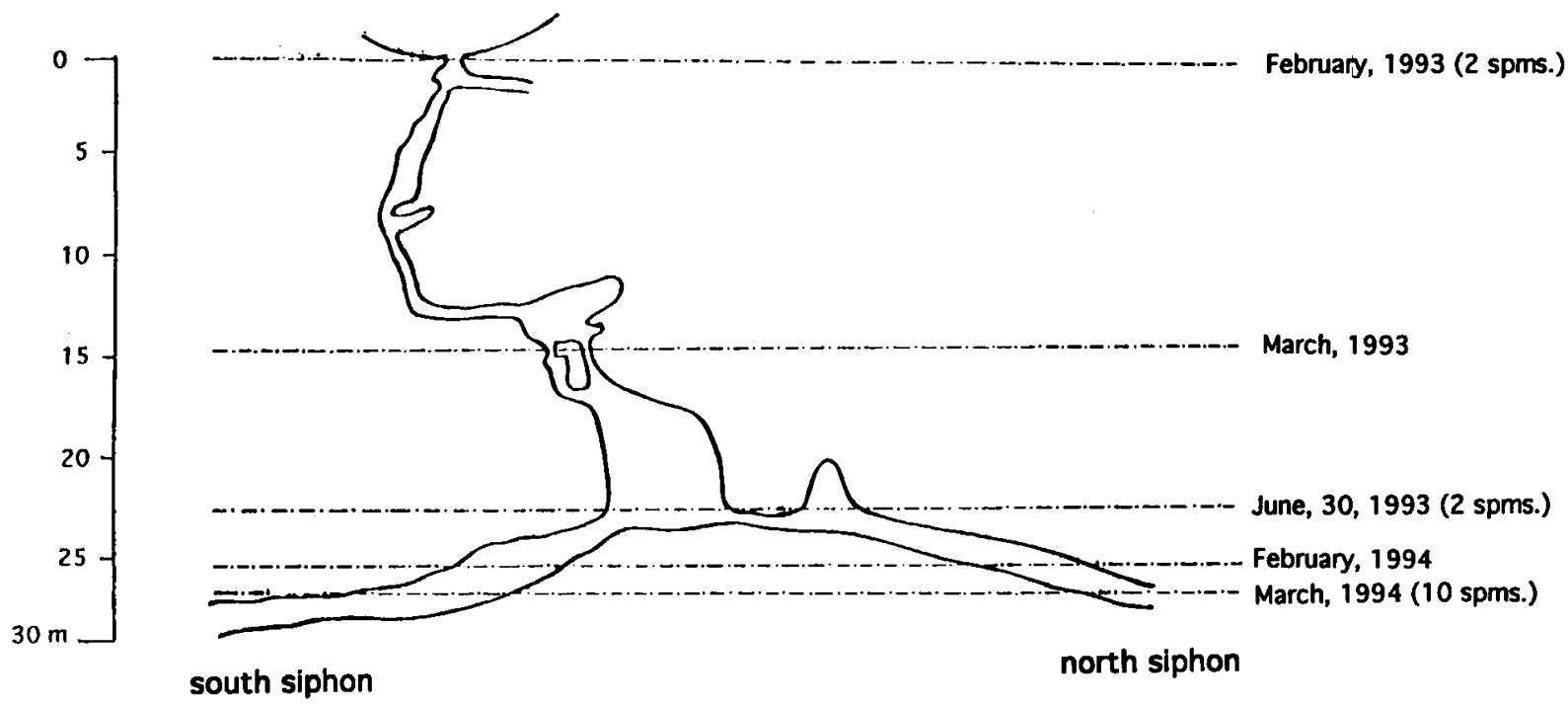

Fig. 6. Profile of the cave. The dotted lines with the dates represent the water level at every exploration. The number of shrimps caught is also given.

Table II. Environmental variables recorded at the first successful sampling in the cave and general geographical information about the cave mouth.

\begin{tabular}{lc}
\hline & $30 T$ YK 504447 \\
UTM coordinates & $140-160 \mathrm{~m}$ above sea level \\
altitude & \\
distance to the sea & $7.75 \mathrm{~km}$ \\
$\quad$ - in direct line & $10.35 \mathrm{~km}$ \\
$\quad$ - by the temporary stream & 24.0 \\
water temperature $\left({ }^{\circ} \mathrm{C}\right)$ & 7.01 \\
pH & -5.4 \\
redox potential & 6.3 \\
dissolved oxygen $(\mathrm{mg} / \mathrm{l})$ & 0.25 \\
salinity $(\% \circ)$ & 615.2 \\
conductivity ( $\mu \mathrm{mhos})$ & 5.15 \\
total alkalinity (mmol/l) & 0.0 \\
phenophtalein alkalinity (mmol/l) & 25.0 \\
chloride (mg/l) & $6.45(\mathrm{meq} / \mathrm{l})$ \\
total hardness $(\mathrm{Ca}++$ plus $\mathrm{Mg}++)$ & $18.0\left({ }^{\circ} \mathrm{dH}\right)$ \\
& $30 / 06 / 93$ \\
date & $9: 00 \mathrm{a} . \mathrm{m}$. \\
hour & \\
\hline
\end{tabular}

careful examination of two specimens of $S$. pretneri (from Kifinoselo, Hercegovina) in the National Museum of Natural History at Leiden, we decide to consider Spelaeocaris as a junior synonym of Typhlatya.

\section{Description of the study area}

(Figs. 5, 6 and Tables II, IV)

In February 1993, members of the Grupo Espeleológico Oropesa del Mar (G.E.O.M.), belonging to the Valencian Speleological Federation, collected two shrimps at the mouth of a cave, called by them "Ullal de la Rambla de Miravet", near Cabanes, in the province of Castellón, eastern Spain. In June 1993, the first author descended into the cave, accompanied by Julio Perpiñá (G.E.O.M. member), and collected two further specimens. In February and March 1994, the cave was visited again and several shrimps were caught.

The cave mouth is located S.S.E. of the town of Cabanes in eastern Spain (see Fig. 5), next to the Cabanes-Orpesa road. The mouth (140-160 m above sea level) is on the bed of a temporary stream known as Rambla de Miravet, or Riu de Xinxilla. Since part of the cave is permanently flooded throughout the year, it has only been explored partially. In Fig. 6 we given an approximate profile of the cave. Before 1992, the entrance was only a narrow cleft from which water flowed after heavy rain. Then, G.E.O.M. members removed rocks, which gave them access to the cave. The water level and number of shrimps caught on each occasion are 
Table III. Habitat and geographical range, with number of known localities, of the species of Typhlatya. References (both for habitat and morphological features): 1, Hobbs et al., 1977; 2, Holthuis, 1986; 3, Botosaneanu \& Holthuis, 1970; 4, Monod \& Cals, 1970; 5, Chace \& Manning, 1972; 6, Hart \& Manning, 1981; 7, Matjašǐ, 1956.

\begin{tabular}{|c|c|c|c|c|}
\hline species & habitat & distribution & No. local. & ref. \\
\hline campecheae & pools in a cave & Campeche, Mexico & 1 & 1,2 \\
\hline garciai & subterranean lake (fresh water) & Cuba & 2 & $1,2,3$ \\
\hline miravetensis & freshwater cave & Castelló, Spain & 1 & $\begin{array}{l}\text { present } \\
\text { study }\end{array}$ \\
\hline monae & $\begin{array}{l}\text { pools in caves or phreatic wells } \\
\text { (mixo- or mesohaline) }\end{array}$ & $\begin{array}{l}\text { Mona Is. (Puerto } \\
\text { Rico), Barbuda \& } \\
\text { Dominican Republic }\end{array}$ & 6 & 1 \\
\hline pearsei & freshwater caves $\&$ cenotes & $\begin{array}{l}\text { Yucatán Peninsula, } \\
\text { Mexico }\end{array}$ & 13 & 1 \\
\hline mitchelli & cenotes (fresh waters) & Yucatán, Mexico & 9 & 1 \\
\hline galapagensis & $\begin{array}{l}\text { from fresh (altitude } 50 \mathrm{~m}, 2 \mathrm{~km} \\
\text { from the coast) to brackish waters, } \\
\text { lava pools and caves }\end{array}$ & $\begin{array}{l}\text { Galápagos Islands } \\
\text { (Sta. Cruz \& Isabela) }\end{array}$ & 5 & 4 \\
\hline consobrina & subterranean lake & Cuba and Caicos Isls. & 3 & $1,2,3$ \\
\hline rogersi & $\begin{array}{l}\text { anchialine habitat of lava } \\
\text { pools, salinity } 35-40 \%\end{array}$ & Ascension Island & 2 & 2,5 \\
\hline iliffei & anchialine habitat in caves & Bermuda & 1 & 2,6 \\
\hline pretneri & caves (fresh water) & Hercegovina & 2 & 2,7 \\
\hline
\end{tabular}

Table IV. Results from a water chemistry analysis performed on March 7, 1994. No "in situ" parameters were measured. Conductivity values are given corrected to $20^{\circ} \mathrm{C}$.

\begin{tabular}{lrc}
\hline & North siphon & South siphon \\
\hline chloride $(\mathrm{mg} / \mathrm{l})$ & 20.0 & 20.0 \\
alkalinity (meq $\left.\mathrm{CO}_{3}^{-}-/\right)$ & 6.4 & 5.45 \\
total hardness & & \\
$\left(\mathrm{Ca}^{++}\right.$plus $\mathrm{Mg}^{++}$) in ${ }^{\circ} \mathrm{dH}$ & 20.0 & 17.0 \\
in meq/1 & 7.2 & 6.1 \\
conductivity ( $\mu \mathrm{mhos}^{2}$ & 610.0 & 550.0 \\
salinity (\%०) & 0.3 & 0.2 \\
\hline
\end{tabular}

also indicated in Fig. 6. The water level was quite variable. Some environmental parameters recorded during the first sampling are shown in Table II as well as some geographical data.

Although the cave is only partially explored, there is sufficient information to suggest that it is not flooded solely by water infiltrating through the soil, but probably mainly by direct water penetration: (1) even though the water was quite transparent, the sediment contained organic matter, not. only fine particulate matter, but also seeds and fragments of leaves; (2) the response to rain is very quick; (3) some $2.5 \mathrm{~km}$ to the northwest (inland) there is an endorheic area called Pla de Cabanes (altitude about $260 \mathrm{~m}$ ), that does not have surface drainage, with two big karstic holes in the centre, where rainwater disappears (see Fig. 5). A more detailed description of the area is given in a bulletin of the "Espeleo Club Castello"' (1985). The cave described in this paper is probably a secondary water exit of the same hydrological system.

\section{The non-anchialine character of the cave}

Anchialine (see Stock et al., 1986; Iliffe, 1992) stands for bodies of haline water, usually with restricted exposure to open air, showing both marine and terrestrial influences. Many species of Typhlatya occur in such habitats (see Table III).

In March 1994, after a period of severe drought, the lowest level since exploration of the cave began was recorded. Then, the cave was sampled again to search for a possible marine influence. For that purpose only main water ions were analyzed. The results of these water analyses are shown in Table IV. No evidence for a marine connection was 
found: neither a tunnel nor water chemistry clues.

The altitude would have caused water to flow to the sea if a connection existed; however, the water is stagnant. It is also possible that complex topography allowed water to stay in siphons. In the unlikely event of a marine connection, it is probably of minor importance, temporary, and with no influence on the main body of the cave, neither on faunal movements, nor on water chemistry changes.

Also, the cave entrance is the only location within a wide area that exhibits the characteristic water surging pattern of strong output in rainy periods and none in dry periods. We believe that the mouth where we penetrated is the main (and probably the sole) exit to the surface of a subterranean drainage system fed from an upper endorheic area. The washing of this area by rainfall appears to supply the organic matter supporting the ecosystem. Anyhow, the cave does not fit with the definition of an anchialine habitat.

\section{Geology, geological history, and paleogeography}

Apart from some sediments carried by the stream, the bed of Rambla de Miravet is made up by Cretaceous materials. The Pla de Cabanes is covered by a slender layer of Quaternary continental deposits lying concordantly on older and thicker Tertiary limnic deposits. This endorheic depression is surrounded by mountains formed by folded and elevated Mesozoic marine deposits (IGME, 1973).

This whole area represents a transition between Iberian and Catalan ranges. Although these ranges have different orientations, they were caused by the same orogeny, one that affected the entire N.E. corner of the Iberian Peninsula. They were formed in the early Tertiary. During this period, tectonic movements related to Alpine orogeny approached the Iberian, Ebro and European plates, giving rise to the Iberian and Catalan mountain ranges (Capote, 1983; Capote \& Carbó, 1983; Santanach, 1983; Martínez López, 1989). These ranges had been mainly areas of marine and lacustrine environments with strong sedimentation processes during the Mesozoic, of a character more shallow than bathyal (Rincón et al., 1983; Canérot, 1991). In the earliest Tertiary, these sediments were uplifted with relatively little folding. During the rest of the Palaeogene, this corner of the Iberian Peninsula represented an elevated area that contained many inner basins with poor drainage to the sea. As at present, shallow-water conditions (freshwater marshes, shallow seas) probably have also prevailed in the coastal areas.

Neogene tectonics affected the entire Iberian and Catalan ranges, but especially this area. Tectonic compressions and distensions in E.S.E.-N.N.W. direction during this period led to the renewed uplift of Mesozoic rocks. These rocks now form a series of mountains that run parallel to the coast (S.S.W.-N.N.E.) from Cabanes, in our study area, throughout the Gandesa/Flix area, some $150 \mathrm{~km}$ to the north (Simón Gómez, 1983; Anadón, 1992). Between these mountains and areas further inland, a series of marshes were trapped. Sediments of the Neogene period were limnic. In the Quaternary, during a period of sea-level regression in combination with dryer conditions, most of these areas emptied, some of them into the sea, others by being transversed by rivers (such as the Ebro), or desiccated by evaporation.

The Pla de Cabanes is a plain area surrounded by an area of complex topography (see Fig. 5). The area is not transversed by rivers. Surface drainage is very difficult. Since the bed underlying the Tertiary and Quaternary deposits is formed by carbonate rocks, it is very likely that drainage of this area started to occur through a subterranean karstic complex that channels water to the mouth we explored.

\section{Distribution}

Hitherto the family Atyidae, to which Typhlatya belongs, was represented in the fresh waters of the Iberian Peninsula by two members only: Atyaephyra desmaresti (Millet, 1831) and Dugastella valentina (Ferrer Galdiano, 1924). Both are epigean freshwater species. The first is distributed in most Iberian basins, draining into both the Atlantic and the Mediterranean. $D$. valentina is an endemism of the eastern Iberian Peninsula where it occurs in a 
narrow zone in the vicinity of the Gulf of Valencia (Sanz \& Gómez, 1984).

The genus Typhlatya is known from the Galápagos Islands, Mexico (Yucatán), Caribbean region, Bermuda, and Ascension Island. The genus group, or "série Typhlatyienne" as defined by Monod \& Cals (1970), consists of the genera Antecaridina, Typhlatya, the former Spelaeocaris, Typhlopatsa, and Stygiocaris, and has a disjunct Tethyan distribution: Typhlatya and Spelaeocaris in the western part (Mediterranean region, Caribbean area, and Galápagos Islands), while Antecaridina, Typhlopatsa, and Stygiocaris occur in the Indo-Pacific area (see Monod, 1975; Holthuis, 1986; Banarescu, 1990).

At present, the new species has only been found in this particular cave.

\section{Discussion}

Members of the genus Typhlatya are found in waters ranging from marine ( $T$. rogersi Chace \& Manning, 1972) to completely fresh (T. miravetensis, T. garciai Chace, 1942, T. pearsei), but generally they occur close to the sea. Although they show the osmotic ability to adapt to fresh water, Typhlatya species do not seem to be able to penetrate further inland. At first sight the distribution pattern seems to be linked to modern shore lines and seas.

Much confusion and controversy exists about the biogeography of the genus Typhlatya. The genus has been widely used for the development of biogeographical models and theories: Rosen's vicariance model for Caribbean biogeography (Rosen, 1976) and Stock's reaction to it (Stock, 1986), a model to explain colonization of anchialine caves in Atlantic islands (Hart et al., 1985), and an alternative approach by Stock (1993).

We think that part of the confusion is the result of the assumption that the evolution of Typhlatya followed the same path as in other genera. For example, in Rosen's model, Typhlatya follows a similar track (however not exactly the same) as other atyids (Atya) and even palaemonids (Macrobrachi$u m$ ). Stock (1986) refutes the use of these decapods because of physiological features like marine dispersal abilities (see below). However, for Typhlatya he points out that this genus seems to fit far better in Rosen's model, except for the fact that one species is known from Ascension island.

All recent Atyidae are freshwater species, but some of them show high salinity tolerances. Hunte (1976a, b) documented the complete larval development of the atyids Mycratya poeyi (Guérin Méneville, 1856) and Atya innocous (Herbst, 1792), reared in the laboratory. He found the optimum larval development at salinities of 32 and $30 \%$, respectively. After these laboratory results he suggested marine stages in the evolution of these species and perhaps other Atyidae. Larval hatching in estuaries has been suggested for Atyoida striolata (McCulloch \& McNeill, 1923) (cf. Smith \& Williams, 1982). On the other hand, the distribution of Atya-related genera, that reached remote islands in the Pacific, certainly does not suggest vicariance events from old marine ranges (see Chace, 1983, for distribution in the Indo-Pacific region).

Even if all recent members of the family Atyidae are freshwater species, the evolutionary euryhalinity, the biogeographical layout, and the age of each genus do not necessarily have to be the same. Banarescu (1973) was the first who stated that (part of) the family Atyidae evolved much earlier into fresh waters than groups such as the palaemonids. At least some of the atyid species are rather salttolerant and "the dispersal of some of them (e.g., the circumtropical and those reaching remote archipelagos in the Pacific) occurred probably in recent times" (Banarescu, op.cit.: 19). On the contrary "a Tethys origin and age must be assumed" for Spelaeocaris, Dugastella, Troglocaris and Palaemonias and perhaps also for Parisia (: 19).

We think that a short review of atyid classification could throw some light on this apparent controversy.

\section{Classification of Atyidae: the "series" concept and its biogeographical meaning}

The main review concerning the family Atyidae is from Bouvier (1925). This author classified the genera known at that time into two kinds of "formes": "forme acanthéphyroïde", with its sole 
genus Xiphocaris, and "formes atyiennes typiques". He divided the "formes atyiennes typiques" in three "séries": "paratyienne", “caridellienne", and "caridienne". To these forms and series he gave an evolutionary meaning. The "forme acanthéphyroïde" (viz. Xiphocaris) would represent the more primitive form, the closest to the ancestral atyid. Among the typically atyan forms, the Caridella and Caridina series would be the more evolved and modern, whilst the Paratya series would represent an intermediate stage. Among the recent families of the suborder Caridea, he placed the closest relatives of the family Atyidae within the family "des Acanthéphyrés", nowadays known as Oplophoridae. In fact, Oplophoridae and Atyidae, together with Nematocarcinidae, often have been grouped within the same superfamily, named Atyoidea (Bowman \& Abele, 1982) or Oplophoroidea (Schram, 1986). Nevertheless, Chace (1992) placed these three families into different superfamilies. He also removed Xiphocaris (the only representative of the "forme acanthéphyroïde" in Bouvier's scheme) from the Atyidae and elevated it to a new family, Xiphocarididae. He placed this new family within the superfamily Nematocarcinoidea.

From the publication of Bouvier's work until 1970 , a number of new atyid genera have been described: Caridines Calman, 1926, Antecaridina Edmonson, 1954 ( = Mesocaris Edmonson, 1935), Typhlatya Creaser, 1936, Parisia Holthuis, 1956, Typhlopatsa Holthuis, 1956, Spelaeocaris Matjašič, 1956, Potimirin Holthuis, 1957 and Stygiocaris Holthuis, 1960. Some of these new genera were difficult to place within Bouvier's scheme. Typhlatya was put into the "Caridinienne" series by Creaser (1936). Holthuis (1956: 98) stated that if one strictly follows Bouvier's key, Typhlatya, Antecaridina, and Typhlopatsa would fall within the "série caridellienne", but these three genera are perhaps more closely related to the genera of Bouvier's "série paratyienne". Later, Holthuis (1965) paid attention to the homogeneity of these genera and their peculiar place in Bouvier's classification and proposed the idea of a separate series. Monod \& Cals (1970) based their "série Typhlatyienne", composed of Typhlatya, Spelaeocaris, Antecaridina, Typhlopatsa, and Stygiocaris on this idea. These authors provided a full review of the morphological features of these genera, making clear their coherence and closest proximity to the Paratya series rather than the Caridina or Caridiella series. Even though they suggested that the morphology and distribution of the series calls for an ancient origin for Typhlatya galapagensis auct. Monod \& Cals (1970) proposed a recent (Miocene or Pliocene) dispersal by the sea from Central America.

Later, Monod (1975) gave a new biogeographical significance to this newly built series. He concluded that the morphology and distributional patterns arose from a common and old origin for the members of this series related to Triassic paleogeography, refuting his older work by including Typhlatya galapagensis in this scheme.

Banarescu (1990) revised the series concept, establishing a different biogeographical layout for each of the four series. He assumed a tropical origin for the entire family, relating the distribution of each series to the position of the tropical zone and the distribution of seas and land masses during the period at which the ancestors of each series left the sea. For example, the Atya/Caridina series (Bouvier's "série caridienne") is pantropical and more or less corresponds to the present-day position of the tropical zone (op.cit.: 511). He assumed that this series did not leave the sea until at least the Pliocene or Pleistocene (: 250). In the case of the Typhlatya series (Monod \& Cals' "série Typhlatyienne") matters would be different; the whole series would have a "Tethyan disjunct range"' (: 238).

Following Banarescu (1990), both the Paratya and Typhlatya series would have been derived from ancient marine stocks. Since these stocks were formed by shallow sea populations, the separation of land masses which characterizes the Mesozoic period made the prawns "land-locked when the land rose, while those which remained marine later became extinct"' (: 250). For the case of Typhlatya, he stated: "In a similar manner the disjunct range of Typhlatya (Antilles, Yucatán, Galapagos and Ascension Islands) can be explained by colonization of the brackish and freshwater caves by representatives of the same marine stock that inhabited the shallow waters, and not by direct continental contact or drifting of Galapagos and 
Ascension Island from the Caribbean area" (: 250). It should be kept in mind that these supposed dispersal abilities concern the species from this "marine stock", viz., the ancestors of the recent species, and not the recent (cavernicolous) species themselves.

\section{Family framework}

Relatively little is known about the origin and biogeography of the Atyidae, except for the fact that the development of each series seems to be different (Banarescu, 1973, 1990).

Recent Atyidae range almost exclusively in fresh waters of both tropical and, considerably less, temperate regions. Their marine ancestors are believed (Bouvier, 1925) to be related to the family Oplophoridae, a group of bathyal shrimps. These primitive marine Atyidae probably occurred in benthic coastal habitats, along warm seas. From here, they would have given rise to the present four freshwater lineages of the Atyidae.

In contrast, recent Palaemonidae have at least as many marine representatives (Palaemon, Pontonia) as freshwater and brackish-water genera (Macrobrachium, Palaemonetes). Following Banarescu (1990: 249-251), the distribution of most freshwater lineages within this family corresponds with the recent distribution of sea and land. Furthermore, freshwater palaemonids are more generally associated with coastal areas, while atyid shrimps tend to be found more in rivers and inland.

The question when this evolution of Atyidae into fresh waters took place and how simultaneously these developments were for the different series remains open. As discussed above, the situation seems far from being coherent and a model cannot be provided for the entire family. If one accepts the present situation of palaemonids as a kind of model for past developments in atyids, it becomes clear that the evolutionary processes are far from being synchronous: among palaemonids some groups are true freshwater species whilst other groups consist of marine, coastal, or intermediate species (brackish, estuarine).

As a result, the distributional patterns of each freshwater lineage would depend on: (1) the position of shore lines at the time that evolution towards fresh waters started to take place; (2) the marine distribution of these ancestors; (3) the length of the period of transition.

Here we want to point out that, while facing the problem of explaining the distribution of animals like Atyidae, or at least its older series, we should better think in ancient coastal marine patterns rather than pelagic marine dispersal, an unlikely supposition, at least for long distances (transoceanic dispersal) and/or for lineages adapted to fresh waters for a long time. Furthermore, if one faces the explanation of the distribution of a genus or species, it is the series (e.g., the "série Typhlatyienne") that is the highest possible framework in which we can move.

\section{Evaluation of former proposals regarding the evolution of the genus}

Croizat, Nelson \& Rosen (1974) dealt with the distribution of Typhlatya as a paradigm of their "vicariance model" viz., as a pattern of species distribution arising from the fragmentation of an old distributional range. Rosen (1976), studying the so-called "tracks" for the Caribbean area, established four kinds of "transoceanic generalized tracks", among which the Typhlatya track represents the oldest. This track would have been derived from an old, late Mesozoic, marine range (see Rosen, 1976: figs. 5E, 6F). He came to this since the Typhlatya track was both amphi-American (Galapagos-Caribbean) and amphi-Atlantic (Caribbean-western Africa).

Our discovery of the genus in the Mediterranean region agrees with these conclusions, but, as will be discussed below, we place the origin earlier than late Cretaceous. At the same time, we think that only now, after the discovery of the genus in Europe, is it possible to assign this kind of track for Typhlatya. Rosen developed his ideas on the basis of the occurrence of $T$. rogersi in "West Africa", meaning Ascension Island, on which this species occurs. This island is located west of the Mid-Atlantic Ridge and probably more related to America than to Africa from a tectonic point of view. Other 
authors also supported vicariance models, but based on morphology and the distributional patterns of the entire series (Monod \& Cals, 1970; Monod, 1975; Banarescu, 1990).

All these models would correspond to a marine ancestor inhabiting shallow waters in the Mesozoic. The later disruption of its range would have led to isolation of the populations due to a low capacity for dispersal. Those races would have given rise to the present cavernicolous species as well as to surface forms that later became extinct. As discussed below, these proposals agree with our findings.

The occurrence of Typhlatya in Atlantic islands, especially in young islands like Ascension Island, led some authors to different conclusions. Some based their ideas on dispersion, others on the existence of ancestral populations as "marine stocks". Chace \& Hobbs (1969) and Peck (1974), dealing with the Antilles, stated that the species dispersed from Central America to these islands in recent times. To explain the occurrence of Typhlatya in Ascension Island, Stock (1986) gave two options: (1) even though the island is young, it is the remnant of an older archipelago; (2) the genus has marine dispersal abilities at a larval stage. Since most Typhlatya species described at the time (but certainly not all) were from anchialine habitats (connected with the sea), he supported the second option, without disregarding the first. Chace \& Manning (1972), referring to the species from Ascension, pointed out that due to the age of the island $T$. rogersi must be a newcomer in these caves, which did not disperse from the continent but originated from a "marine stock". They did not point out how ancient this stock might be, if it was bathyal or pelagic, with or without dispersal capabilities, and how its geographical distribution would have been. Iliffe et al. (1983), dealing with this problem and with the occurrence of $T$. iliffei in Bermuda, stated that both species could originate from a marine stock associated to the Mid-Atlantic Ridge, where they had persisted since "the separation of the African and American continental masses". They did not think that this stock was as ancient as Tethyan, even though they stressed that in these caves true Tethyan relicts occur, as the hippolytid shrimp Somersiella sterreri Hart \& Manning, 1981.
A more dispersalist model came from Hart et al. (1985) who, while reviewing the fauna of Atlantic caves, proposed for most of the taxa a dispersive evolution from (very old) ancestors, mainly bathyal or pelagic. Including Typhlatya in their species review, they came to conclude: "however, it is even more difficult to create a scenario for their dispersal" (op.cit.: 289). As will be discussed below, we do not think that this is the case in Typhlatya.

The model provided by Stock (1993) seems to fit better the Typhlatya situation. This author pays attention to the fact that "many stygobionts have congeneric relatives in shallow marine waters", and he explains the occurrence of several taxa, including Typhlatya, on Atlantic islands: "the young islands must have existed as shallow banks or seamounts in the period when the Atlantic started to open, and before the disruption of the Tethys Sea" (Stock, 1993: 807). It is important to pay attention to the two paleogeographical conditions argued by this author, since they are important to establish an estimated age for the genus: the Atlantic Ocean was opening and the Tethys was not completely closed. Our findings agree with this, especially for Typhlatya. Furthermore, this takes the Typhlatya track from Stock's third track (amphi-atlantic/eastern Pacific) to an older track (amphi-atlantic/eastern Pacific/Mediterranean). Further development of these ideas can be found in Stock (1994).

\section{Troglobiosis}

With regard to the occupation of freshwater subterranean habitats by crustaceans, several mechanisms and evolutionary scenarios have been suggested. For interstitial and crevicular subterranean fauna the proposed models (Stock, 1980; Coineau \& Boutin, 1992; Notenboom, 1991) assume troglobites evolved from marine (coastal) interstitial organisms that occurred in areas of frequent shoreline changes. However, free-swimming freshwater animals from caves may not have evolved directly from marine ancestors, but rather from surface freshwater forms (Barr \& Holsinger, 1985; Holsinger, 1988).

A different explanation can be given for animals 
occurring in former anchialine habitats. It is possible that anchialine environments could have lost their connection with the sea, for example by sealevel changes. If freshwater influence occurred, this would have become the organizing factor for the system. In this case, it is not a surface population that evolved towards a subterranean species, but rather it is the cave itself that changed from marine to freshwater conditions. Subsequently, the populations either break the osmotic barriers or they disappear. Since true anchialine habitats are usually quite variable in salinity (depending on tides, freshwater input, etc.), the hypothesized populations may have been pre-adapted to change (Hutchinson, 1960; Peck, 1974).

\section{A model for the evolution of the genus}

Now, let us try to provide a model for the evolution of the genus largely based on the ideas exposed by the authors cited in previous sections. We based our model on Tethyan paleogeography and paleoceanography, the ecology of recent species, and on the finding of a member of the genus in Europe, all within the "series" framework.

The occurrence of the genus in Europe is a strong clue to link the origin of the genus Typhlatya to the Tethys Sea, following Monod, Banarescu, and Stock. The ancestor probably was a marine, coastal shrimp, ranging in low latitudinal seas, such as the Mediterranean, the mid Atlantic, the Gulf of Mexico and the eastern Pacific (the western part of the Tethys Sea). These seas covered a much smaller area during the Mesozoic than at present. The only living descendants of this species are found in cave habitats. Monod (1975) related the present range of Typhlatya to Triassic paleogeography. The paleogeograpnical reconstructions we have consulted do not support this. In order to determine the period at which this ancestor may have occupied its continuous range before it was disrupted, a look into Tethys paleogeography is needed.

In the early Triassic, when the Pangea supercontinent started to break up, the western part of the Tethys Sea more or less corresponded with the present eastern Mediterranean-Middle East area
(Stampfli et al., 1991). The progressive breakup of Pangea reached the Iberian Peninsula during the mid Triassic.

In the early Jurassic, a rift valley system was developing in the central North Atlantic (Jansa, 1991). As a result, in the Pliesbachian (194-200 mY ago) an incipient marine passage through America was opened, connecting the western Tethys and the eastern Pacific (Riccardi, 1991). From this point and during the rest of the Jurassic, the Central Atlantic continued to widen, resulting in a change of circulation pattern from an estuarine to an "open channel" type (Jansa, 1991). The Iberian Peninsula was in the middle of this passage, surrounded by a channel between Iberia and Europe (Biscay Seaway) and another between Iberia and Africa (Rift Seaway) (see San Román \& Aurell, 1992; Schwentke \& Kuhnt, 1992; Reicherter et al., 1994).

In the early Cretaceous, the Central AtlanticCaribbean connection between the Mediterranean Tethys and the eastern Pacific was fully opened, and a connection with the Arctic by the just opened North Atlantic was made (Scotese, 1991). As a consequence, following Winterer (1991: 261): "the circum-global west-flowing equatorial current system established in Late Jurassic time was now less restricted through the Mediterranean, Central Atlantic and Caribbean, and the most typical of all Tethyan faunas, the rudists, spread widely around the globe, from about $30^{\circ} \mathrm{N}$ to $30^{\circ} \mathrm{S}$ '. Also in the early Cretaceous, the South Atlantic started its rifting phase, from south to north. This seaway was not opened until the Albian-Cenomanian $(90 \mathrm{mY}$ ago) (Riccardi, 1991; Scotese, 1991). Later, in the Turonian, faunal exchanges between the opened South Atlantic and the Mediterranean-Central Atlantic-Caribbean-East Pacific system, were possible both through the establishment of a current system in the whole Atlantic and the Sahara Seaway. The late Cretaceous paleogeography (from Santonian to Maastrichtian, 87-65 mY ago), marks the acme of the global Tethyan Ocean. From here on the trend is toward constriction in low latitudes (Winterer, 1991).

We think that the maximal development of the ancestral range of Typhlatya should be situated 
somewhere in the Turonian (where the South Atlantic was opened) and the latest Maastrichtian/ early Cenozoic (end of the global Tethys). It is most likely that these ancestors existed before this period (ranging in the Mediterranean-Caribbean-Eastern Pacific) and it is then that they achieved their maximal expansion, once they had colonized shallow areas in the South Atlantic. It is not very likely that the genus developed much earlier than this period: there are two genera of the series in the western Tethys (Typhlatya and the former Spelaeocaris) and three more in the eastern Tethys (Antecaridina, Typhlopatsa, and Stygiocaris).

We do not think that the genus Typhlatya could have evolved later than this period. In that case we face new obstacles: the mentioned seas were separated by deep ocean basins with restricted circulation between them. The finding of a member of the genus at the eastern side of the Iberian Peninsula, isolated in this period from the Tethyan global current, makes this option very unlikely. To overcome this, we would have to postulate a pelagic or bathyal atyid shrimp with good dispersal abilities giving origin to the present-day Typhlatya. As discussed, the supposition of bathyal or pelagic ancestors for any member of the family (and even more of the series) is far from likely.

Additional problems connected with the supposition of a relatively recent evolution from a marine atyid would be: (1) a more pronounced morphological similarity between geographically close species would be expected; (2) even with exceptions, as Munidopsis polymorpha Koelbel, 1892, there are relatively few anchialine animals related with marine bathyal or pelagic taxa (Iliffe, 1992; Stock, 1993, 1994); (3) dispersal through the seafloor is only possible for cold-adapted species and Typhlatya is tropical or temperate as are most of the Atyidae.

Since anchialine caves are rich in "ancient" fauna (Iliffe, 1992; Iliffe et al., 1984; Stock, 1994), this early origin should not come as a surprise. On the other hand, the fauna of the Iberian Peninsula is rich both in taxa that are undoubtedly Tethyan or have amphi-Atlantic/Mediterranean tracks, e.g., Atyidae of the Paratya series, Stenasellidae, Cirolanidae (Isopoda), Bogidiellae, Hadziidae, Ingolfiellidae (Amphipoda), Parabathynellidae (Bathy- nellacea), and cyprinodontiform fishes (for a review, see Banarescu, 1991).

We suppose that the split up of the distributional area of the ancestor into several isolated areas (both by plate tectonics and by the change of global current systems) happened more or less simultaneously. This does not mean that further evolutionary development of each of these populations was either simultaneous or even of the same kind. Once isolated in coastal populations, separated by deep seas, each local population could have evolved in different ways conditioned by: (1) physical and geological factors: presence of caves (limestone or lava types) near the coast, presence of fresh or brackish water bodies, depth and morphology of the coasts or shallow banks, presence of emerged lands (in case of shallow banks), etc.; (2) biotic factors: presence of competitors in the sea, presence of competitors in the fresh waters near the shore, food availability in the caves, etc.

In Fig. 7 we give a schematic representation of our proposal for the evolution of the genus. A marine species would have ranged along the eastern Tethys coasts about the end of the Cretaceous. This species represents the nearest shared ancestor of the present-day species. The full opening of the Atlantic Ocean and the end of the global Tethyan currents divided its range in at least three populations. European and central American populations were still linked to the coasts, while Mid-Atlantic Ridge populations remained in shallow sea banks. Like several authors (Iliffe et al., 1983; Banarescu, 1990; Stock, 1993), we believe that those shallow sea banks may have existed from this period and sank later on. Winterer (1991) made a revision of the evolution of guyots, reefs and seamounts on the oceanic crust of the Pacific. He concluded that many of these seamounts were as old as the Barremian (Early Cretaceous). During the late Cretaceous "there was an important episode of development of reefs and carbonate banks around and on top of the subsidiary seamounts". Furthermore, during the Eocene, those Cretaceous seamounts "were rejuvenated and uplifted by renewed vulcanism" (Winterer, 1991: 264).

The period of coastal existence must have been short for the European species, otherwise the find- 


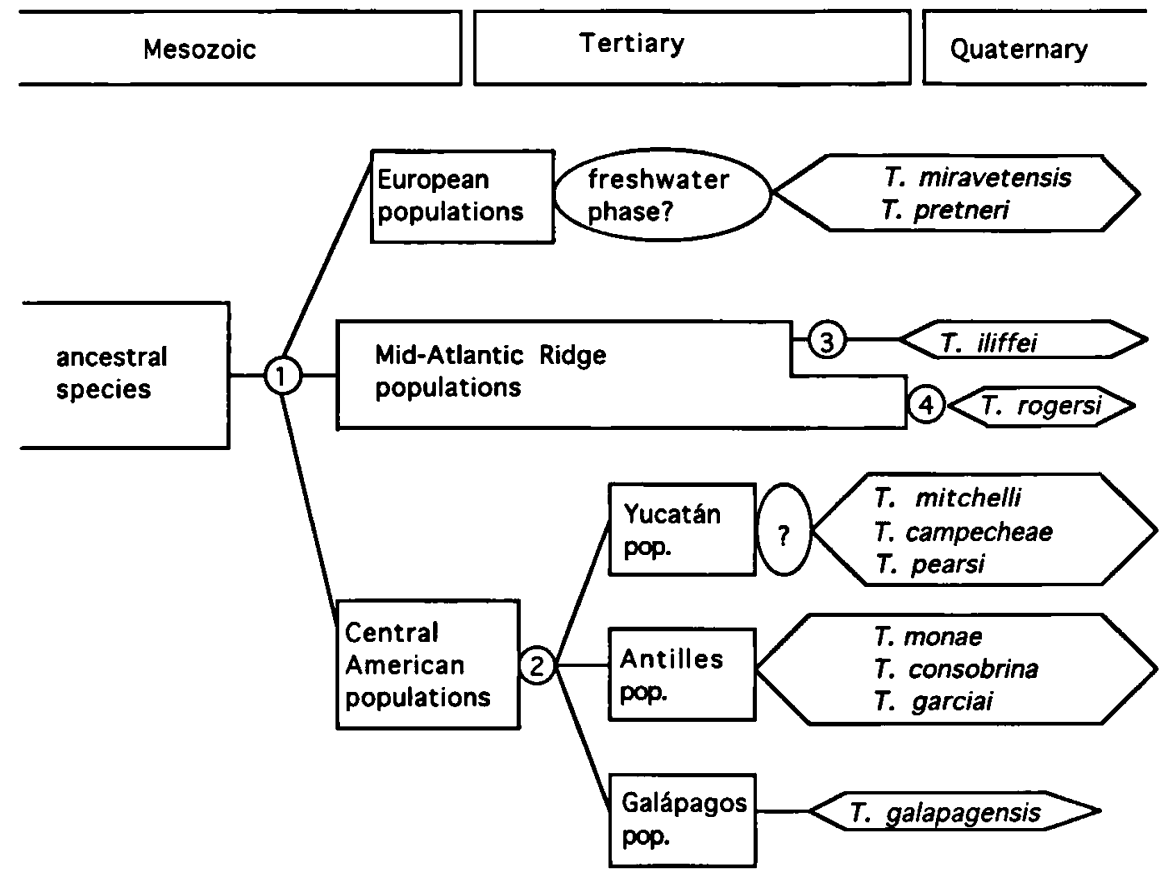

Fig. 7. Summarized scenarios for the evolution of the genus Typhlatya. Rectangles represent marine (coastal) populations or species. Ellipses are fresh- or brackish-water forms. Hexagons are troglobitic species. Major geological events: (1) opening of the Atlantic Ocean; (2) division, by plate tectonics, of ancestral Central America; (3) uplifting of Bermuda; (4) uplifting of Ascension Island. The time scale is not proportional. The time of events is only approximative. For a detailed explanation, see text.

ing of more recent Typhlatya in this area would be expected. For unknown reasons (cold weather, competition, etc.) these populations soon disappeared. Only those species survived that evolved earlier into a cave environment. In Central America, the marine stock was again divided by plate tectonics into three main populations: continental Central America, proto-Antilles, and Galápagos Islands (for a revision of the geological history of the area see Rosen, 1976). These populations quickly disappeared, after giving rise to the present Typhlatya of the area. In some cases, especially in the species from the continent, it would have been possible that these species first passed through a freshwater phase. The populations that remained marine for a longer period of time were those linked to the Mid-Atlantic Ridge. They reached the caves in a relatively recent period, when islands emerged. This may explain why $T$. rogersi (Ascension) and $T$. iliffei (Bermuda) still retain eye pigmentation and are found among the more haline species (see Tables I \& III).
A representation of the ecological evolution of the species of the genus is provided in Fig. 8. Following this model, there would have been two ways to evolve to the cave environment: (1) into anchialine (or paleoanchialine) caves directly from the sea; (2) evolving first to brackish waters, then to fresh waters and finally to caves, like $T$. miravetensis in our scenario (see below). It must be stressed that as soon as a species evolves to a cave habitat, genetic isolation from the rest is produced. Many recent members of the genus do not inhabit anchialine habitats (for example the Yucatan and European species, as can be seen in Table III). We have no evidence to prove it, but even for true anchialine species it is hard to think of mechanisms of dispersal from one cave to another because: (a) in most cases the caves are separated from each other by long distances and deep sea arms (and we are dealing with shallow and warm-temperate water adapted animals); (b) large quantities of offspring would be needed; (c) there are "couples" of different species inhabiting geographically nearby localities (e.g., 


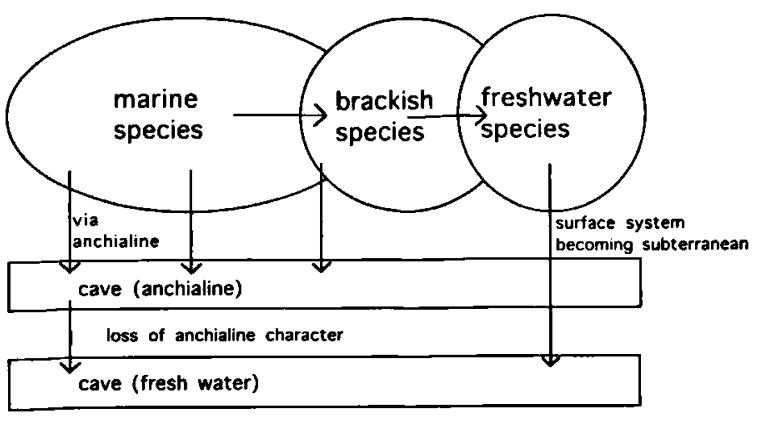

Fig. 8. Summarized scenarios for the ecological evolution of the genus Typhlatya. For further explanation, see text.

T. garciai and T. consobrina Botosaneanu \& Holthuis, 1970). Nevertheless, for very nearby caves, dispersal after speciation may be assumed as an hypothesis.

In our model, we allow dispersalist explanations only in the evolutionary stages previous to troglobiosis. Cretaceous ancestors were able to disperse, and they probably occupied the South Atlantic when it opened from its older Caribbean-Central Atlantic-Mediterranean range. But as the areas were separating further, the more the currents became local, and the species evolved into brackish, freshwater or cavernicolous forms, transoceanic dispersal became impossible. Within each of the three main areas (see Fig. 7), dispersal at local scale could have occurred, for example between islands in the Antilles. But here we mainly mean marine, brackish, or even freshwater ancestral populations in evolutionary stages where the haline behaviour could have allowed low-range dispersal through the sea, as it seems to have happened in recent times within species of the genus Atya.

\section{Morphological patterns}

Some morphological characters of the recent species of the genus are shown in Table I. Even if there are not too many features listed, the absence of any pattern can easily be recognized. Geographically distant species often show more similarity than species from the same area. In this case there are no patterns linked to habitats.
Perhaps the proposed model could provide an explanation for the absence of patterns. One reason to explain this could be that isolation seems to have taken place early, not only between the three main lineages, but also early within each lineage. The other reason could be that, after division, the intermediate ancestors of each recent species could have been affected by quite different selection pressures, depending on how much time was spent in the seas, which events led to troglobiosis, etc. As a result, some species have retained plesiomorphous character states, whilst others became apomorphous (fusion of ischium and merus, reduction of rostrum, reduction of fifth pereiopod, loss of eye pigment, etc.).

For clarifying these patterns and schedule, every particular evolutionary event and a detailed cladistic analysis, using as much characters as possible, would be needed. It would be even more important to study the adaptative significance of every single character in detail.

Evolutionary scenario for T. miravetensis

The previously espoused ideas are very important as background to place the evolution of this new species in space and time. Our model is based on the paleogeographical evolution of the area, and the fact that the ancestors of $T$. miravetensis were isolated, from the late Cretaceous onwards. These ancestors would have occupied the shallow waters of the present-day Iberian/Catalonian ranges during the Cretaceous. Alpine orogenesis uplifted the sediments of these shallow waters and led to the birth of the Iberian and Catalonian ranges. The shoreline moved towards a position near its present location. From here we have two options: (1) some populations remained trapped in swamp areas or lowland rivers (the situation at Pla de Cabanes during the Paleogene) inside those ranges or between the mountains and the sea; (2) the ancestors of $T$. miravetensis followed the sea in its retreat and occupied the Mediterranean shore.

Neogene tectonics led to the elevation of surrounding areas, making drainage difficult. The 
swamp started to open a karstic system in the limestone rocks underneath the bed of limnic sediments. This induced the slow drainage of the swamp. Permanent water bodies developed in the resulting cave system. If the swamp kept being occupied by shrimps (first option), the population evolved towards a cavernicolous species into this more stable habitat. Even if relatively quick (Ginés \& Ginés, 1992), the duration of karstification would have been slow enough for the shrimps to evolve towards the occupation of cavernicolous habitats.

It is also possible that after alpine orogenesis the swamps did not retain shrimps and colonization of the cave system (once it was opened in the Neogene) took place from the Mediterranean shore, as in other Typhlatya populations in limestone caves or lava tubes connected to the sea in other parts of the world. The geological evolution would be the same as in the other option. The only difference may be that subterranean drainage did not lead water to a low lying area but directly to the sea, giving rise to an anchialine habitat of the "limestone cave" type. A further marine regression (perhaps a consequence of Neogene tectonics too) would have isolated the mouth from the sea. The surface water source ensures the permanence of water and, subsequently, of the shrimps.

Both options are in agreement with geological data. There is only a minor difference: the existence of a former connection of the subterranean system with the sea. But here crucial geological information is missing.

\section{Acknowledgements}

The authors are deeply indebted to Julio Perpiñá, not only for providing us with the first two shrimps, but also for his help in obtaining the permission to enter the cave from the Valencian Speleological Federation. His information on cave topography, including the map, and his active collaboration in sampling was of great help. Francesc Mezquita (Unitat d'Ecologia, Universitat de València) is thanked for his valuable assistance in sampling. We wish to thank Profs. Frederick Schram and Jan H. Stock for their constructive review of a preliminary version of this manuscript, and Dr. C.H.J.M. Fransen of the Nationaal Natuurhistorisch Museum, Leiden for providing us with the Spelaeocaris material. The fieldwork has been financed by the project AMB-0430 from the Spanish C.I.C.Y.T. The first author received a pre-doctoral grant from the Conselleria d'Educació i Ciència of the Generalitat Valenciana.

\section{References}

Anadón, P., 1992. Les fosses i depressions neògenes, sector meridional. In: J. Guimerà (coord. ed.), Geologia II. Història Natural dels Països Catalans, 2: 340-345 (Enciclopèdia Catalana, S.A. Barcelona).

Banarescu, P., 1973. On Tethys marine remnants in fresh waters. Revue roum. Biol. Zool., 18(1): 15-21.

Banarescu, P., 1990. Zoogeography of fresh waters, 1. General distribution and dispersal of freshwater animals: 1-511 (Aula-Verlag GmbH, Wiesbaden).

Banarescu, P., 1991. Zoogeography of fresh waters, 2. Distribution and dispersal of freshwater animals in North America and Eurasia: 524-1087 (Aula-Verlag GmbH, Wiesbaden).

Barr, T.C., Jr. \& J.R. Holsinger, 1985. Speciation in cave faunas. Ann Rev. Ecol. Syst., 16: 313-337.

Botosaneanu, L. \& L.B. Holthuis, 1970. Subterranean shrimps from Cuba (Crustacea Decapoda Natantia). Trav. Inst. Spéol. Emile Racovitza, 9: 21-133.

Bouvier, E.L., 1925. Recherches sur la morphologie, les variations et la distribution systématique des Crevettes d'eau douce de la famille des Atyidés. Encyclopédie Entomologique, (A) 4: 1-370 (Lechevalier, Paris).

Bowman, T.E. \& L.G. Abele, 1982. Classification of the recent Crustacea. In: L.G. Abele (ed.), The biology of Crustacea, 1. Systematics, the fossil record, and biogeography: 1-27 (Academic Press, New York).

Canérot, J., 1991. Comparative study of the eastern Iberides (Spain) and the western Pyrenees (France) Mesozoic basins. Palaeogeogr., Palaeoclimatol., Palaeoecol., 87: 1-28.

Capote, R., 1983. La tectónica de la Cordillera Ibérica. In: J.A. Comba (coord. ed.), Libro Jubilar J.M. Ríos. Geología de España, 2: 108-120 (Instituto Geológico y Minero de España, Madrid).

Capote, R. \& A. Carbó, 1983. La evolución tectónica de los Dominios de Plataforma e Intermedios. In: J.A. Comba (coord. ed.), Libro Jubilar J.M. Ríos. Geología de España, 2: 37-47 (Instituto Geológico y Minero de España, Madrid).

Chace, F.A., Jr., 1983. The Atya-like shrimps of the IndoPacific region (Decapoda: Atyidae). Smithson. Contr. Zool., 384: 1-54.

Chace, F.A., Jr., 1992. On the classification of the Caridea (Decapoda). Crustaceana, 63(1): 70-80.

Chace, F.A., Jr. \& H.H. Hobbs, Jr., 1969. The freshwater and terrestrial decapod crustaceans of the West Indies with special reference to Dominica. Bull. U.S. natn. Mus., 292: 1-258.

Chace, F.A., Jr. \& R.B. Manning, 1972. Two new caridean shrimps, one representing a new family, from marine pools on Ascension Island (Crustacea: Decapoda: Natantia). Smithson. Contr. Zool., 131: 1-18. 
Coineau, N. \& C. Boutin, 1992. Biological processes in space and time: colonization, evolution and speciation in interstitial stygobionts. In: A.I. Camacho (ed.), The natural history of biospeleology: 423-452 (Monografías del Museo Nacional de Ciencias Naturales; C.S.I.C., Madrid).

Creaser, E.P., 1936. Crustaceans from Yucatan. In: A.S. Pearse, E.P. Creaser \& F.G. Hall, The cenotes of Yucatan. A zoological and hydrographic survey. Publs. Carnegie Instn., 457: 117-132.

Croizat, L., G. Nelson \& D.E. Rosen, 1974. Centers of origin and related concepts. Syst. Zool., 23: 265-287.

Espeleo Club Castelló, 1985. El forat de l'Horta (Cabanes). Centre d'Estudis de la Plana, Butlletí n ${ }^{\circ} 3$, juliol-septembre 1985.

Ginés, A. \& J. Ginés, 1992. Karst phenomena and biospeleological environments. In: A.I. Camacho (ed.), The natural history of biospeleology: 27-56 (Monografías del Museo Nacional de Ciencias Naturales; C.S.I.C., Madrid).

Hart, C.W., Jr. \& R.B. Manning, 1981. The cavernicolous caridean shrimps of Bermuda (Alpheidae, Hippolytidae and Atyidae). J. crust. Biol., 1(3): 441-456.

Hart, C.W., Jr., R.B. Manning \& T.M. Iliffe, 1985. The fauna of Atlantic marine caves; evidence of dispersal by sea floor spreading while maintaining ties to deep waters. Proc. biol. Soc. Wash., 98: 288-292.

Hobbs, H.H., Jr., H.H. Hobbs, III \& M.A. Daniel, 1977. A review of the troglobitic decapod crustaceans of the Americas. Smithson. Contr. Zool., 244: 1-183.

Holsinger, J.R., 1988. Troglobites: the evolution of cavedwelling organisms. Am. Scient., 76: 147-153.

Holthuis, L.B., 1956. The troglobic Atyidae of Madagascar (Crustacea Decapoda Natantia). Mém. Inst. scient. Madagascar, (A) 11: 97-110.

Holthuis, L.B., 1965. The Atyidae of Madagascar. Mém. Mus. natn. Hist. nat., (N.S.) (A, Zool.) 33(1): 1-48.

Holthuis, J.B., 1986. Decapoda. In: L. Botosaneanu (ed.), Stygofauna mundi: 589-615 (E.J. Brill, Leiden).

Hunte, W., 1976a. The complete larval development of the freshwater shrimp Micratya poeyi (Guérin-Méneville) reared in the laboratory (Decapoda, Atyidae). Crustaceana, Suppl. 5: $153-166$.

Hunte, W., 1976b. The complete larval development of the freshwater shrimp Atya innocous (Herbst) reared in the laboratory (Decapoda, Atyidae). Crustaceana, Suppl. 5: 231-242.

Hutchinson, G.E., 1960. On evolutionary euryhalinity. Am. J. Sci., (Bradley Volume), 245(A): 98-103.

IGME (Instituto Geológico y Minero de España), 1973, Mapa geológico de España E. 1:50.000. Hoja N616 "Villafamés", $2^{a}$ serie, $1^{a}$ edición (Servicio Publicaciones Ministerio de Industria, Madrid).

Iliffe, T.M., 1992. Anchialine cave biology. In: A.I. Camacho (ed.), The natural history of biospeleology: 613-636 (Monografias del Museo Nacional de Ciencias Naturales; C.S.I.C., Madrid).

Iliffe, T.M., C.W. Hart, Jr. \& R.B. Manning, 1983. Biogeo- graphy and the caves of Bermuda. Nature, 302: 141-142.

Iliffe, T.M., H. Wilkins, J. Parzefall \& D. Williams, 1984. Marine lava cave fauna: composition, biogeography, and origins. Science, 255: 309-311.

Jansa, L.F., 1991. Processes affecting paleogeography, with examples from the Tethys. Palaeogeogr., Palaeoclimatol., Palaeoecol., 87: 345-371.

Martínez López, N., 1989. Tendencias en paleobiogeografía. In: E. Aguirre (coord. ed.), Paleontología: 271-296 (S.C.I.C., Madrid).

Matjašič, J., 1956. Ein neuer Höhlendecapode aus Jugoslawien. Zool. Anz., 157(3-4): 65-68.

Monod, T., 1975. Sur la distribution de quelques Crustacés Malacostracés d'eau douce ou saumâtre. Mém. Mus. natn. Hist. nat., (A, Zool.), 88: 98-105.

Monod, T. \& P. Cals, 1970. Sur une espèce nouvelle de Crevette cavernicole: Typhlatya galapagensis (Decapoda Natantia; Atyidae). Mission Zoologique Belge aux Iles Galapagos et en Ecuador, 2: 57-103.

Notenboom, J., 1991. Marine regressions and the evolution of groundwater dwelling amphipods (Crustacea). J. Biogeogr., 18: 437-454.

Peck, S.B., 1974. The invertebrate fauna of tropical American caves, part II: Puerto Rico, an ecological and zoogeographic analysis. Biotropica, 6(1): 14-31.

Reicherter, K., T. Pletsch, W. Kuhnt, J. Manthey, G. Homeier, J. Wiedmann \& J. Thurow, 1994. Mid-Cretaceous paleogeography and paleoceanography of the Betic Seaway (Betic Cordillera, Spain). Palaeogeogr., Palaeoclimatol., Palaeoecol., 107: 1-33.

Riccardi, A.C., 1991. Jurassic and Cretaceous marine connections between the Southeast Pacific and Tethys. Palaeogeogr., Palaeoclimatol., Palaeoecol., 87: 155-189.

Rincón, R., L. Vilas, C. Arias, A. García Quintana, J.R. Mas, A. Alonso \& N. Meléndez, 1983. El Cretácico de las Cordilleras Intermedias y Borde de la Meseta. In: J.A. Comba (coord. ed.), Libro Jubilar J.M. Ríos. Geología de España, 2: 79-103 (Instituto Geológico y Minero de España, Madrid).

Rosen, D.E., 1976. A vicariance model for Caribbean biogeography. Syst. Zool., 24: 431-464.

San Roman, J. \& M. Aurell, 1992. Palaeogeographical significance of the Triassic-Jurassic unconformity in the north Iberian basin (Sierra del Moncayo, Spain). Palaeogeogr., Palaeoclimatol., Palaeoecol., 99: 101-117.

Santanach, P., 1983. Los Catalánides. In: J.A. Comba (coord. ed.), Libro Jubilar J.M. Ríos, Geología de España, 2: 120130 (Instituto Geológico y Minero de España, Madrid).

Sanz, A. \& P. Gómez, 1984. Distribución geográfica de Dugastella valentina (Ferrer Galdiano, 1924) (Crustacea, Decapoda, Atyidae). Limnética, 1: 336-339.

Schram, F.R., 1986. Crustacea: i-xvi, 1-606 (Oxford University Press, New York).

Schwentke, W. \& W. Kuhnt, 1992. Subsidence history and continental margin evolution of the Western Pyrenean and Basque Basins. Palaeogeogr., Palaeoclimatol., Palaeoecol., 95: 297-318. 
Scotese, C.R., 1991. Jurassic and Cretaceous plate tectonics reconstructions. Palaeogeogr., Palaeoclimatol., Palaeoecol., 87: 493-501.

Simón Gómez, J.L., 1983. Neotectónica de la región del Maestrazgo. In: J.A. Comba (coord. ed.), Libro Jubilar J.M. Ríos. Geología de España, 2: 446-448 (Instituto Geológico y Minero de España, Madrid).

Smith, M.J. \& W.D. Williams, 1982. Taxonomic revision of Australian species of Atyoida Randall (Crustacea: Decapoda: Atyidae), with remarks on the taxonomy of the genera Atyoida and Atya Leach. Aust. J. mar. freshwater Res., 33: 343361 .

Stampfli, G., J. Marcoux \& A. Baud, 1991. Tethyan margins in space and time. Palaeogeogr., Palaeoclimatol., Palaeoecol., 87: 373-409.

Stock, J.H., 1980. Regression model evolution as exemplified by the genus Pseudoniphargus (Amphipoda). Bijdr. Dierk., 50(1): 105-144.

Stock, J.H., 1986. Caribbean biogeography and a biological calendar for geologicals events. In: R.H. Gore \& K.L. Heck (eds.), Crustacean biogeography: 195-203 (A.A. Balkema, Rotterdam).

Stock, J.H., 1993. Some remarkable distribution patterns in stygobiont Amphipoda. J. nat. Hist., 27: 807-819.

Stock, J.H., 1994. Biogeographic synthesis of the insular groundwater faunas of the (sub)tropical Atlantic. Hydrobiologia, 287: 105-117.

Stock, J.H., T.M. Iliffe \& D. Williams, 1986. The concept "anchialine"' reconsidered. Stygologia, 2(1/2): 90-92.

Winterer, E.L., 1991. The Tethyan Pacific during Late Jurassic and Cretaceous times. Palaeogeogr., Palaeoclimatol., Palaeoecol., 88: 253-265.

Received: 14 September 1994

Accepted: 18 May 1995

\section{Appendix}

\section{Key to the species of the genus Typhlatya}

1 a Eyes pigmented $\ldots \ldots \ldots \ldots \ldots \ldots \ldots \ldots \ldots \ldots \ldots 2$

b Eyes without pigment $\ldots \ldots \ldots \ldots \ldots \ldots \ldots \ldots \ldots$

2 a Ischium and merus of all pereiopods separate ...... 3

b Ischium and merus in at least one pair of pereiopods fused $\ldots \ldots \ldots \ldots \ldots \ldots \ldots \ldots \ldots \ldots \ldots \ldots$

3 a Exopodite of fifth pereiopod reaching well beyond ischiomeral articulation ........... T. garciai Chace, 1942

b Exopodite of P5 reduced, not reaching ischiomeral articulation ................... T. monae Chace, 1954

4 a Ischium and merus of all pereiopods fused ........... $\ldots \ldots \ldots \ldots \ldots \ldots$.
Ischium and merus $P 1$ and 2 fused, $P 3$ to 5 articulate ... ..............T. rogersi Chace \& Manning, 1972

5 a Rostrum short, not reaching beyond second antennular

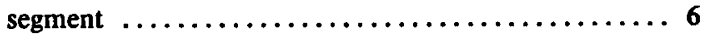

b Rostrum reaching well beyond second antennular seg-

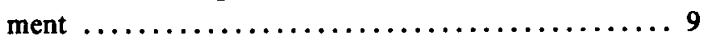

6 a Ischium and merus of all pereiopods separate $\ldots \ldots \ldots 7$

b Ischium and merus in $\mathrm{P} 3-4$ fused $\ldots \ldots \ldots \ldots \ldots 8$

7 a Rostrum not reaching beyond eyestalk, telson with two lateral and no dorsal spines .....T. miravetensis $\mathrm{n}$. sp.

b Rostrum reaching beyond eyestalk, telson with four dorsal spines ......... T. campecheae Hobbs \& Hobbs, 1976

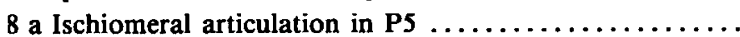
T. mitchelli Hobbs \& Hobbs, 1976

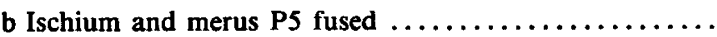
............ T. galapagensis Monod \& Cals, 1970

9 a Exopodite P5 reaching well beyond ischiomeral articulation .... T. consobrina Botosaneanu \& Holthuis, 1970

b Exopodite P5 reduced, shorter than total length of basipodite ........................... 10

10 a Exopodites P1-4 setose ...... T. pearsei Creaser, 1936

b Exopodites P1-4 not setose ... T.pretneri (Matjašǐ, 1956) 